\title{
Distinctive duration of speech sounds in Estonian
}

1.

Estonian is a language which distinguishes between more than two degrees of duration of speech sounds. There are three distinctive degrees of duration in both vowels and consonants in Estonian.

The existence of three degrees of quantity in Estonian was recognized and first investigated by an Estonian linguist of the 19 th century, M. Weske. ${ }^{1}$ Pertinent laboratory experiments and phonetic measurements have been made at the University of Estonia at Tartu and the problem has been investigated from the phonetical point of view especially by P. Ariste. ${ }^{2}$

The interesting phenomenon of three distinctive quantities has also stimulated linguists of other countries to deal with the subject and to express their views. However, most of them have been handicapped by a lack of knowledge of Estonian and by insufficiency of data published in languages familiar to them; therefore they incline to mold the Estonian quantitative system into that of the languages of which they have a better knowledge. 'Thus, for example, what N. Trubetzkoy had to say about Estonian duration ${ }^{3}$ was based on erroneous material and his conclusions were entirely incorrect.

Recently L. Posti tried, but unsuccessfully, to reconcile the

1 In his dissertation, Untersuchungen zur vergleichenden Grammatik des finnischen Sprachstammes (Leipzig, 1872), pp. 6-18.

2 e.g. "A Quantitative Language», Proceedings of the Third International Congress of Phonetic Sciences (Ghent, 1939), pp. 276-280.

3 e.g. Grundzüge der Phonologie (Prague, 1939), p. 178. 
three distinctive degrees of quantity in Estonian with the theory of only two degrees, assuming that the long and overlong durations are allochrones of the same, long chroneme. ${ }^{1}$ Daniel Jones, however, correctly registered the principle of three distinctive degrees of duration (three chronemes) in Esto$n^{n i a n}{ }^{2}$. B. Collinder compared Estonian degrees of duration with those of Lapp, which is another language with a complicated quantitative system. ${ }^{3}$

Marguerite Durand made some experiments in Paris concerning Estonian duration (unfortunately there are a number of errors in the presentation of the Estonian material). ${ }^{4}$ As regards the relation between duration, voice pitch and stress in Estonian, the most detailed and reliable data have been published by Elin Põldre, ${ }^{5}$ who made phonetic experiments under the direction of $\mathrm{P}$. Ariste in the laboratory of phonetics in Tartu, with informants from different Estonian dialect regions; her experiments showed that voice pitch generally is conditioned by duration in Estonian: the longer the stressed vowel the higher the pitch curve rises (with some differences in pitch in different dialects); however, pitch is more consistently connected with and determined by stress - the stronger the stress the higher the tone.

In a recent article $A$. Raun dealt with the Estonian quantitative system. ${ }^{6}$ He assumed that the absence of an original consonant which has been lost in Estonian represents an additional, zero degree of quantity, viz. in cases in which,

1 "On Quantity in Estonian," Journal de la Société Finno-ougrienne (abbrev. JSFOu.) LIV (1948-50), 1-14.

2 The Phoneme: Its Nature and Use (Cambridge, 1950), e.g. pp. 121, 127, 132 f.; "Chronemes and Tonemes . . ., Acta Linguistica IV (1944), 5.

3 Recently in "Three Degrees of Quantity," Studia Linguistica V, 1. (1951), 28-43.

4 See e.g. Voyelles longues et voyelles brèves (Paris, 1946), pp. 78-89, fig. nos. $48-58$.

5 "Intonatsiooni, kvantiteedi ja dünaamilise rōhu suhteist eesti keeles." [ = On the relation between intonation, quantity, and dynamic accent in Estonian.] Eesti Keel XVI (1937), 164-183, with a short summary in French.

B Studia Linguistica VIII (1954), 62-76. 
as result of the loss of a weak counterpart of an intervocalic stop, the vowels of the original first and second syllables have been contracted into one vowel or diphthong. However, this vowel or diphthong is actually overlong in modern Estonian, e.g. in Est. vee gen. sg. 'of the water' < Proto-Finnic *veden, the vowel of which now has the same overlong duration as that of tee 'road, way', which is a Proto-Finnic long vowel. ${ }^{1}$

Because of the increasing interest in the remarkable system of duration in Estonian and the insufficiency of internationally available pertinent material, it seems necessary to present the following data.

2.

When we compare, for example, the Estonian words sada 'hundred' - saada imperat. 2nd sg. 'send' - saada inf. 'to get' we find that the distinctive feature is the duration of the first, stressed, vowel $-a$. It is SHORT in the first word, LONG in the second, and in the third it has the greatest degree of length which is customarily called overLong (or extra long). In textbooks they are usually called first, second, and third duration respectively.

Similarly there are contrasting examples like kadus imperf. 3rd sg - katus 'roof' - kattus reflex. act. im'disappeared' perf. 3rd sg. 'became covered'

kalas inessive sg. - kallas 'shore, - kallas imperf. 3rd sg. 'in the fish' river bank' 'poured'

linu partitive pl. - linnu gen. sg. - linnu partitive pl. 'flax, sheets' 'of the bird' 'cities'

which are distinguished only by different duration degrees of the consonant that follows the stressed (first-syllable) vowel: in kadus, kalas and linu it is short, in katus, kallas 'shore'

1 Some errors have slipped into the material presented, mainly into the transcription (e.g. $w$ instead of $v, \dot{\omega} \omega$ instead of $\dot{v})$. 
and linnu 'of the bird' it is long, or a short geminata, as it is usually called, although (as phonetic experiments prove) no "gemination» actually exists; in kattus, kallas 'poured' and linnu 'cities' the relevant consonant is overlong (or what is called a long geminata). The letter $d$ denotes the lenis stop, a voiceless media (as also $b$ and $g$ designate the respective mediae), which differs from the corresponding tenuis only as to duration, essentially, since the Estonian tenues are unaspirated. ${ }^{1}$

The existence of three different degrees of duration in Estonian is confirmed by laboratory experiments. The following data, based on sound spectrograms which I made in 1954 in Ithaca, N. Y., U.S.A., ${ }^{2}$ may illustrate it.

According to my experiments, the duration of a short vowel in an open first (i.e. stressed) syllable (as in abi 'help', sada 'hundred', etc.) varied between 0.11 and 0.15 seconds, the duration of a long vowel spoken at the ssames speed and under the same environmental and accentual conditions (as in saada imperat. 2nd sg. 'send' etc.) between 0.17 and 0.23 sec., and that of an overlong vowel (as in saada inf. 'to get', uude illat. sg. of uus 'new', etc.) between 0.27 and 0.37 sec. The average duration of the short vowel was 0.12 sec., that of the long vowel 0.20 sec., and overlong $0.32 \mathrm{sec}^{3}$ Thus the average

1 In Estonian orthography all three degrees of duration are distinguished for stops in intervocalic and final position after a short vowel: the letters $b, d, g$ denote the short, $p, t, k$ the long, and $p p, t t, k k$ the overlong sounds. In recent loanwords $\check{z}, \check{s}$ and $\check{s} \check{s}$ mark the three degrees of duration of the same sibilant; $f$ denotes the short as well as long and $f f$ the overlong labio-dental spirant (these letters do not occur in indigenous words). In other cases the orthography differentiates between short and long duration of vowels as well as consonants, but not between the long and overlong degrees (because of the inconvenience of writing three letters or employing other means, which have occasionally been experimented with formerly).

2 I wish here to express my thanks to Professor J. M. Cowan, Director of the Division of Modern Languages of Cornell University, for permission to use the sound spectrograph of the university.

3 According to former measurements secured by Ariste, who used the kymograph, the three durations of vowels were about 10,25 and 35 hundredths of a second respectively (Proceedings of the Third Intern. Congr. of Phon. Sc., 227). 
long degree of duration of vowels is ca. 1.6 times longer than the short degree, and the overlong degree is 1.6 times longer than the long degree.

The short degree of duration of intervocalic consonants ${ }^{1}$ (as in abi 'help', sada 'hundred', liade 'envious', etc.) varied within the range of 0.05 to 0.10 sec., the long degree (as in kate 'cover', ute gen. sg. 'of the ewe', kukub pres. 3rd sg. 'falls', etc.) 0.16 to 0.18 sec., and the overlong degree (as in appi illat. sg. 'help!', katte gen. sg. 'of the cover', etc.) 0.26 to 0.34 sec. The average durations were as follows: short degree 0.065 sec., long degree $0.17 \mathrm{sec}$, and overlong degree $0.30 \mathrm{sec}$. The long degree of a consonant, thus, is ca. 2.6 times longer than the short, and the overlong degree is ca. 1.8 times longer than the long. The overlong degree is 4.6 times longer than the short. - In trisyllabic and longer words, all vowels and consonants are shorter.

To be sure, the absolute (actual) duration of sounds depends on the tempo of speaking. For this reason it is usually advantageous to operate with relative durations. These can be obtained with the following equation: Relative Duration equals Absolute Duration (Absolute Word Duration) divided by Number of Sounds. ${ }^{2}$ It works perfectly for languages which have only two degrees of distinctive duration and do not combine short vowels with short consonants and long vowels with long consonants. However, for Estonian, which makes use of three degrees of duration in various combinations, it often fails. For example, the relative duration of $u u$ - before a long consonant in uute gen. pl. of uus 'new' as well as of oo-before an overlong consonant in oota imperat. 2 nd sg. 'wait' (ma- inf. ootama) often is 1 , although the first vowel is long and the second is overlong; even the relative duration of the short $a$ in $a b i$ 'help, aid' sometimes is the same, namely 1 (usually in a sentence or phrase if the word is non-final). Furthermore, in $u$ ute as well as in oota the relative duration of both the first-

1 For the most part stops were used in the experiments, in order to gain a clearly marked borderline of the beginning and end of consonants for exact measurements (note that Est. stops are not aspirated).

2 This method is used by G. Panconcelli-Calzia. 
syllable vowel and the consonant very often is the same, ca. 1, although in uute both are long and in oota they are overlong. Therefore it is more appropriate for the present purpose to take the average absolute (actual) durations of sounds in words which are pronounced at approximately the same speed and to compare the averages of these degrees of duration, as was done above.

The accumulation of length in the types such as $d a$ - inf. saata 'to send' (ma- inf. saatma), imper. 2nd sg. oota 'wait' (ma- inf. ootama), part. sg. sööki 'food' (nom. söök), gen. sg. saapa 'of the boot' (nom. saabas) is an especially interesting case. Some more examples: $d a$ - inf. keeta 'to cook, boil (trans.)', töötada 'to work' (ma- inf. keetma, töötama), imperat. 2nd sg. tööta 'work', pres. töötan 'I work' etc., imperf. töötasin 'I worked' etc.; nom. sg. jook 'beverage, drink', part. sg. jooki, paati 'boat'; part. pl. saapaid 'boots' (nom. sg. saabas), jooke 'beverages'; gen. sg. toote (nom. toode) 'of the product', tööka (nom. töökas) 'laborious'; nom. pl. saapad 'boots'; oblique cases, e.g. iness. sg. saapas 'in the boot', iness. pl. jookides 'in beverages', etc. The average absolute duration of the vowel of the first syllable in separately spoken words was 0.22 sec. (the variation lying between 0.20 and $0.27 \mathrm{sec}$.), and the average duration of the following consonant was $0.23 \mathrm{sec}$. (with variation 'between 0.21 and $0.29 \mathrm{sec}$.) according to my experiments. Both durations are thus longer than the normal average long degree of a vowel before a short consonant and of a consonant after a short vowel (which is 0.20 for the vowels and 0.17 for the consonants), but shorter than overlong ( 0.32 for the vowels, 0.30 for the consonants). However, it is to be expected that they are shorter, because a vowel regularly is shortened when it is immediately followed by a long or overlong consonant, and a consonant is shortened when preceded by a long or overlong vowel (see the intermediate durations below). In this case both environmental influences coincide. Therefore the duration of the consonant is somewhat shortened, but it is still closer to the range of variations found in the overlong degree than to the range found in the long degree; thus its duration clearly belongs to the overlong degree. The duration 
of the vowel is considerably shorter than the overlong duration of the vowel before a short consonant; but since its variations still are longer than those of the long degree (although their ranges partly overlap) and since also its average is longer, then, regarding the shortening environmental influence, the vowel too must be considered as having a shortened overlong degree of duration. This becomes especially clear if we compare these cases with those in which the duration of both the vowel and the consonant belongs to the long degree, e.g. overlong in gen. sg. toote 'of the product' (nom. toode) - long in toote pres. 2nd pl. 'you bring, fetch' (ma- inf. tooma), overlong diphthong and consonant in gen. sg. köite 'of the volume, of the binding' (nom. köide) - long in gen. pl. köite 'of the ropes' (nom. sg. köis), etc. The long vowel and the immediately following long consonant in uute gen. pl. of 'new' (uus), köite 'of the ropes', saate pres. 2 nd pl. 'you get, ( $m a$-inf. saama), etc., are shortened, too; their average durations were ca. 0.18 sec. (variation $0.17-$ $0.19 \mathrm{sec}$.) and ca. $0.16 \mathrm{sec}$ (variation $0.13-0.19 \mathrm{sec}$.) respectively.

Thus there are three distinctive degrees of durations in Estonian; however, phonetic experiments show an additional number of durations which are determined by the duration of their environment. Before an overlong or long consonant (especially a stop) the duration of a vowel is shorter than usual, as is the case with the overlong degree in saata, oota, etc., and with the long degree in uute, saate, etc. Phonetically, the durations of stressed vowels can be distinguished and grouped as follows (with the Finno-Ugric phonetic transeription which distinguishes between different phonetic lengths added in square brackets):

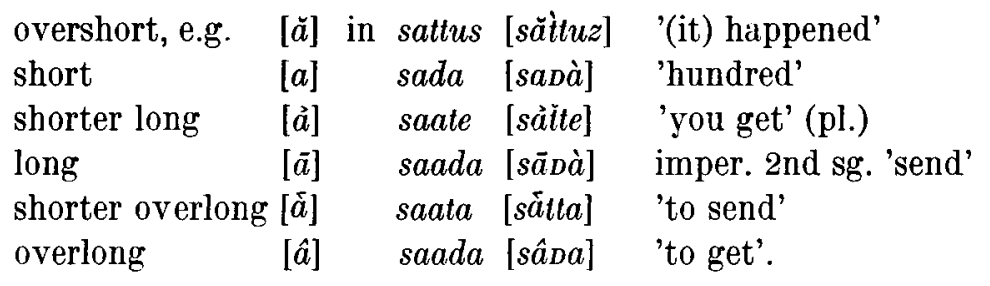


'The average lengths of the vowels in question are, according to my experiments, as follows: overshort ca. 0.10 sec., short 0.12 sec., shorter long ca. 0.18 sec., long 0.20 sec., shorter overlong $0.22 \mathrm{sec}$, overlong $0.32 \mathrm{sec}$. On the other hand the degree of duration of a consonant is shorter after a long or overlong vowel, e.g. the stop is overlong in sattus [sattuz] but shorter overlong in saata [sătta], and the long $[\check{t} t]$ is somewhat shorter in saate [sätte] (or transcribed more specifically as [săttè] than in katus [kattuz]. Likewise a long or overlong consonant is shorter when preceded by another consonant, e.g. shorter overlong in kurku [kurkku] part. sg. 'throat'. The average durations of the relevant consonants are: short 0.065 sec., shorter long ca. 0.16 sec., long 0.17 sec., shorter overlong 0.23 sec., overlong 0.30 sec. It is obvious that these intermediate durations are entirely determined by their environment and are not distinctive. They constitute three pairs of variants of the three distinctive degrees respectively.

3.

All speech sounds occur with all three distinctive durations ( $h, v$ and $j$ appear only with short durations except for some dialects and in loanwords or descriptive words). Diphthongs, however, are only long or overlong, i.e. the second component is either as long as the first or longer; for example, both components are short in laulud nom. pl. 'songs', seinal adess. sg. 'on the wall', laeva gen. sg. 'of the ship', laulan pres. 1st sg. 'I sing', the second component is longer in laulu part. sg. 'song', seina part. sg. 'wall', laevu part. pl. 'ships', laulda inf. 'to sing', etc.

It is a characteristic feature of the Estonian quantitative system that combinations of various degrees of duration are possible:

short V + short C, e.g. sada 'hundred', elame 'we live', rohelised n. pl. 'green'

" V + long C, e.g. ike 'yoke', tammed n. pl. 'oaks', annate pres. 2 nd pl. 'you give' 
》 $\mathrm{V}+$ overlong C, e.g. tamme part. sg. 'oak', ikked n. pl. 'yokes', sepp 'smith', julgeme (overlong $l$ ) pres. 1st pl. 'we dare'

long $\mathrm{V}+$ short $\mathrm{C}$, e.g. joogid 'beverages', tuule gen. sg. 'of the wind', sööme pres. 1st pl. 'we eat' " $\mathrm{V}+$ long $\mathrm{C}$, e.g. uute köite g. pl. 'of the new ropes', joote pres. 2nd pl. 'you drink'

overlong $\mathrm{V}+$ short C, e.g. puud n.pl. 'trees', soola part. sg. 'salt', tiibu part. pl. 'wings', kuulama 'to listen', kuulma 'to hear' overlong $\mathrm{V}+$ overlong C,e.g. oota imper. 2nd sg. 'wait', saata 'to send', leeki part. sg. 'flame', töötame pres. 1st pl. 'we work'.

Short vowels and short consonants occur in every syllable, either stressed or not, e.g. küsimused 'questions', lubadega 'with permits', in which every vowel and consonant is short. Long and overlong vowels exist only in the first (i.e. strongly stressed) syllable, for example, long in tuuled nom. pl. 'winds' and soovitame 'we recommend', overlong in toored nom. pl. 'raw' and keelasime 'we forbade'. Diphthongs, however, can occur also in unstressed syllables, chiefly in the partit. pl. of the contract type, e.g. rattaid 'wheels' (n. sg. ratas). Long consonants occur immediately after strongly stressed vowels, and in suffixes and inflexional endings as well, either with secondary stress or in unstressed position, e.g. in koputate 'you knock' (plur.) all intervocalic consonants are long, in tuulikutesse 'into the wind-mills' $-k-$, $-t$ - and $-s s$ - denote long consonants. Overlong consonants occur after the vowel with primary stress as well as in derivative suffixes and inflexional endings with secondary stress, e.g. juttudesse illat. pl. 'into the stories, tales' (overlong -tt- and $-s s^{-}$), laevastikku part. sg. 'fleet' (overlong $-k k-)$, esimesse kirikusse illat. sg. 'into the first church' (overlong $-s s$ - in both words). Overlong (actually shorter overlong) consonants occur also in clusters immediately following the stressed vowel. The first or the second consonant of a cluster can be overlong, e.g. $t$ in atra part. sg. 'plow', $l$ in selge 'clear', $s$ in vastan pres. 1st sg. 'I answer'; $k$ in võrku part. sg. 'net', 
$s$ in kirssi part. sg. 'cherry'; in a cluster of three or more consonants either the first or a medial consonant can be overlong, but not the last, e.g. $m$ in numbrid nom. pl. 'numbers', $t$ in kortsus 'wrinkled', $s$ in värske 'fresh', $t$ in vintske 'tough', etc.

Every monosyllabic word in normally stressed position contains an overlong sound, either the vowel or a following consonant (if there is any), e.g. overlong vowel in puu 'tree', öö 'night', ööd 'nights', kool 'school', au 'honor', overlong consonant in all 'under, underneath', sepp 'smith', tamm 'oak', kirss 'cherry' (overlong $s$ ), etc.; or both are (shorter) overlong, e.g. saak 'prey', niit 'thread', etc.

4.

As is seen from the examples given above, different degrees of duration of one sound, either the stressed vowel or the immediately following consonant, can distinguish between different words. A regular alternation of degrees of duration also can occur in the same paradigm and duration can be the only distinctive feature of different inflexional forms. Duration thus has semantic and morphological functions in Estonian.

A different degree of duration is the only distinctive feature of different morphological forms in word types with disyllabic stem and gradation, such as:

LONG (2nd degree) overlong (3rd degree)

Nom. sg. genitive sg. partitive sg.

$\begin{array}{lll}\text { sepp 'smith': } & \text { sepa } & \text { seppa } \\ \text { kukk 'cock': } & \text { kuke } & \text { kukke } \\ \text { jutt 'story, tale': } & \text { jutu } & \text { juttu } \\ \text { mäss 'revolt': } & \text { mässu } & \text { mässu } \\ \text { linn 'city': } & \text { linna } & \text { linna } \\ \text { sool 'salt': } & \text { soola } & \text { soola } \\ \text { piim 'milk': } & \text { piima } & \text { piima } \\ \text { laul 'song': } & \text { laulu } & \text { laulu (overlong dipht- } \\ & & \text { koera ( " }\end{array}$




\begin{tabular}{|c|c|c|}
\hline & nominative sg. & genitive sg. \\
\hline & ike 'yoke' & ikke \\
\hline & $\begin{array}{c}\text { hoone 'building, } \\
\text { house' }\end{array}$ & hoone \\
\hline & laine 'wave' & laine \\
\hline & nominative sg. & inessive sg. \\
\hline & ratas 'wheel' & rattas 'in the wheel' \\
\hline & $\begin{array}{r}\text { põõsas }{ }^{1} \text { 'bush, } \\
\text { shrub' }\end{array}$ & põõsas \\
\hline & kaunis 'beautiful' & kaunis \\
\hline & partitive sg. & elative $\mathrm{sg}$. \\
\hline ratas 'wheel': & ratast & rattast 'from the wheel' \\
\hline $\begin{array}{c}\text { kallis 'expensive, } \\
\text { dear': }\end{array}$ & , kallist & kallist \\
\hline toores 'raw': & toorest & toorest \\
\hline & genitive pl. & illative sg. \\
\hline vesi 'water': & vete & vette 'into water' \\
\hline ma-inf. & imperative 2 nd sg. & $d a$-infinitive \\
\hline jätma 'to leave': & jäta & jätta \\
\hline & sHon'l (1st degree) & overLong (3rd degree) \\
\hline nom. sg. & genitive sg. & partitive sg. \\
\hline ader 'plow': & $a d r a$ & atra (overlong $t$ ) \\
\hline silm 'eye': & silma & silma (overlong $l$ ) \\
\hline kurk 'throat': & kurgu & kurku (overlong $k$ ) \\
\hline & nominative sg. & illative sg. \\
\hline & tuba 'room' & tuppa 'into the room' \\
\hline & partitive sg. & illative sg. \\
\hline jōgi 'river': & jõge & jōkke \\
\hline
\end{tabular}

1 The Estonian letter $\dot{o}$ denotes a mid back-central unrounded vowel. 
nominative sg. inessive sg.

ablas 'voracious' aplas (overlong $p$ )

partitive sg. $\quad$ elative sg.

ablas 'voracious': ablast

aplast (overlong $p$ )

ma-inf. imperative 2nd sg. $\quad d a$-infinitive

kartma 'to fear karda karta (overlong $t$ )

be afraid':

etc.

Here we see a distinctive alternation of long and overlong or short and overlong durations of certain speech sounds.

The alternation of duration occurs in the stressed syllable, either in the duration of the vowel with primary stress or of the immediately following consonant or of the second (or third) consonant of a cluster, as is the case in the examples presented above. Primary stress falls on the first syllable in Estonian (except in recent loanwords, especially scientific terminology, which usually retain the foreign stresses). The alternation of duration of stops occurs also in suffixes with secondary stress, e.g. part. sg. kasulikku 'useful' - gen. sg. kasuliku; part. laevastikku 'fleet' - gen. laevastiku; part. kanarbikku 'heather' - gen. kanarbiku. Secondary stress usually falls on the third syllable if it is non-final, or on the second syllable if a suffix with quantitative alternation is added to a monosyllabic stem (these cases are not numerous), e.g. part. sg. maastikku 'landscape' - gen. sg. maastiku (from maa 'earth, land'). ${ }^{1}$

1 There are also paradigms which show no variation in duration but in which different grammatical forms are usually distinguished by (partly) retained inflexional endings, e.g. gen. sg. pere - part. sg. peret 'family' or $\mathrm{g}$. rohelise - p. rohelist 'green', in which both the stressed vowel and the following consonant remain short, g. hapu - p. haput 'sour' with a long $p$-sound (2nd degree) in both, g. kuulsuse - p. kuulsust 'fame' with overlong $u$-sound in the first syllable. In other paradigms again the weakening of the consonant of original forms with alternation of duration has resulted in changes of quality, e.g. part. sg. sõda 'war' - gen. sg. sõja, p. härga 'ox' - g. härja, p. tiiba 'wing' - g. tiiva, etc., or in entire loss of the consonant, which has 
The reasons for the alternation of duration are historical. It originates partly from Proto-Finnic gradation, according to which stops originally had a longer degree at the beginning of an open syllable and a shorter degree at the beginning of a closed syllable, e.g. modern Est. part. sg. seppa 'smith' gen. sg. sepa, or it originates from the expansion of gradation to all speech sounds, e.g. part. sg. kooli 'school' with overlong $o$ - gen. sg. kooli with long $o$. In this case the overlong degree of a consonant or vowel alternates paradigmatically with the long degree. Partly, however, different degrees in different forms of the same word have resulted from the loss of weak consonants between the 1st and 2nd syllable (yielding regular alternation through the whole paradigm), e.g. part. sg. jalga 'foot' with overlong $l-$ gen. sg. jala (with short $l$ ), or from the loss of a consonant between non-initial syllables (in some inflexional forms), e.g. illat. sg. tuppa 'into the room' (from *tupahan) - cf. nom., part. sg. tuba. The alternation of the overlong degree of duration of a sound with the short degree originates from later phonological changes, which consist either in the lengthening of a sound, e.g. illat. sg. tuppa, or in the shortening, e.g. gen. sg. kurgu 'of the throat' (from *kurkkkun).

Also all loanwords and even late borrowings have been adapted to the Estonian quantitative patterns including the alternation of duration, e.g. nom. sg. šokk '(nervous) shock', part. sg. šokki - gen. sg. šoki; nom. šeff 'boss', part. šeffi gen. šefi; nom. sport 'sport', part. sporti - gen. spordi; nom. film '(movie, photo) film', part. filmi with overlong $l-$ gen. filmi (short l); nom. staar 'movie star', part. staari with overlong vowel - gen. staari with long vowel, etc. Similarly foreign proper names are pronounced with one of the three distinctive degrees of duration according to the Estonian patterns and likewise show alternation of duration, e.g. part. Churchilli with overlong $l-$ gen. Churchilli with long $l$; part. Rooma with overlong $o-$ gen. Rooma with long $o$; illat. New Yorki 'to

caused new and different conditions of duration, e.g. part. sg. lugu 'tale, story' - gen. sg. loo with overlong vowel, p. viga 'mistake' - g. sea, pl ólga 'shoulder' (with overlong $l$ ) - g. óla. etc. 
New York' - iness. New Yorgis 'in New York', etc. The quantitative system with three degrees and regular alternation is one of the most characteristic features of Estonian pronunciation. Incidentally, it therefore is one of the last peculiarities of Estonian pronunciation, if not the very last, which remains when the Estonian speaker learns a foreign language.

5.

The duration of the vowels of $\mathrm{n}$ on-in it i a l syllables (which are unstressed or weakly stressed) is not distinctive in Estonian. This must be especially emphasized since attempts have been made to assign phonemic significance to the duration of the vowel of the second syllable. ${ }^{1}$ Phonetically, the vowels of non-initial syllables can be either short, prolonged to quarteror half-long or even long, e.g. the final vowel is usually a socalled "half-long» one, [à], in sada [savà] 'hundred'. However, these prolonged durations are determined by their quantitative environment. ${ }^{2}$ The duration of the vowel of the seccnd syllable is determined by the duration of the following consonant (or cluster) and by the duration of the preceding syllable. It is longer than the short vowel of the first (stressed) syllable under two coexistent conditions: if it is preceded by no overlong consonants or vowels in the first syllable and if it is final or followed by one short consonant. Some examples: sada 'hundred', elu 'life', elan 'I live', majad 'houses', tamme (gen. sg.) 'of the oak'. It is longer after a short first syllable than after a long first syllable (with a sound of 2nd degree), and it is the longest in absolute final position in disyllabic words if the first syllable is short (i.e., the first vowel is short and is followed by only one short consonant), as in sada 'hundred',

1 L. Posti, JSFOu. LIV, $1-14$.

2 According to A. Raun, Studia Linguistica VIII, 62 \& 64, J. Mägiste (Meddelanden från seminarierna för slaviska språk, jämförande språkforskning och finsk-ugriska språk vid Lunds Universitet I (1951), 5-12) has pointed out that half-long duration in the second syllable is a Begleiterscheinung". Raun himself also states that half-long duration vis not phonemic in Estonian», op. cit., 64. 
uba 'bean', kala 'fish'. However, it is a well-known phonetic fact that an unstressed final vowel whose duration is not distinctive generally tends to be longer. ${ }^{1}$ The duration of the final vowel in the English word city, for example, is, according to Daniel Jones, ${ }^{2} 0.175$ sec., while the duration of the first vowel is only 0.054 sec.: thus the unstressed vowel of the second syllable is more than three times longer than the short stressed vowel. Likewise in Estonian the average absolute duration of the final vowel of the second syllable in single, separately pronounced words, i.e. in absolute final position, is, according to my spectrograms, the following: ca. 0.20 sec. after a short first syllable (varying between 0.11 and $0.34 \mathrm{sec}$.), and ca. 0.18 after a long (not overlong) first syllable (varying between 0.12 and $0.25 \mathrm{sec}$.). Thus in the first case it has even the full length of a long vowel. However, after an overlong first syllable the duration, under similar conditions of absolute final position again, was almost the same -0.17 sec. (varying between 0.14 and $0.21 \mathrm{sec}$.). On the other hand, in trisyllabic or longer words it was again the final vowel, not the second, that was considerably longer than the average short stressed vowel, with an average duration of ca. 0.16 sec. (varying between 0.13 and 0.22 sec.). In this case the vowel of the 2nd syllable was either only slightly longer than the average short one - viz. in the open 2nd syllable of trisyllabic words with a short first syllable - or even shorter. However, the duration of the final vowel of disyllabic words in normally stressed position in a sentence usually remains somewhat longer than the stressed short vowel only if (1) the vowel of the first syllable is short and followed by a short single consonant a n d if (2) it is word-final or, when followed by one short consonant, the next word begins with a vowel. The duration of the vowel in a closed 2nd syllable, however, is generally shorter than the standard short duration. The word opikute (gen. pl.) 'of the textbooks', in which all vowels are followed

1 See, e.g., G. Panconcelli-Calzia, Die experimentelle Phonetik in ihrer Anwendung auf die Sprachwissenschaft (Berlin, 1924), p. 118.

2 The Phoneme, pp. $128 \mathrm{f}$. 
by a stop with long degree of duration (a "geminata», which closes the preceding syllable), is a good example to illustrate this situation: the durations of the vowels of this word in my experiments, when pronounced separately, were: $\tilde{o}^{-} 0.10,-i$ $0.08,-u-0.07,-e 0.17$ sec., and $0.11-0.08-0.08-0.15$ and $0.10-0.07-0.07-0.20$ sec. respectively when the word was repeated. The average duration of a vowel in a closed 2nd syllable was $0.12 \mathrm{sec}$. after a short first syllable and $0.09 \mathrm{sec}$. after a long (not overlong) first syllable (varying between 0.05 and 0.13 sec.).

All this illustrates that the duration of the vowel of the second syllable is not distinctive in Estonian. It is the unstressed vowel that, for phonetic reasons, tends to be prolonged to strike a kind of balance of duration after short sounds, since its duration simply is not distinctive; the duration of the stressed vowel, which is distinctive, cannot be changed without changing the meaning of the word. According to these factors, the duration of unstressed vowels in the second syllable varies within a very large range - between 0.05 and 0.34 sec. (between 0.11 and 0.34 sec. in the open second syllable). L. Kettunen already pointed out that the duration of the so-called halflong vowel varies as much as from $3.4 \mathrm{~mm}$ to $15 \mathrm{~mm}$, while the average length of a short vowel was $7.2 \mathrm{~mm}$ according to his measurements. ${ }^{1}$ So great an inconsistency and overlapping of degrees of duration, if distinctive, could not be endured for the sake of clearness and comprehensibility in a language that makes use of three distinctive degrees of duration. This is not the case with the durations of vowels in stressed syllable; here, for example, a long rowel that precedes a long consonant, although shortened in this position, still remains considerably longer than a short vowel. On the other hand, while the average duration of the so-called half-long vowel of separately pronounced disyllabic words is (according to my measurements) ca. 0.19 sec. in final position, its average duration is only ca. 0.10 sec. (i.e. shorter than average short in stressed position) when it is followed by a long consonant or cluster. The absence

1 B. Collinder, Studia Linguistica V, 29 f.

11 - Finnisch-ugrische Forschungen 
of "half-long» duration in this last case is illustrative evidence for the fact that it is not distinctive but is determined by its quantitative environment.

Thus an attempt to build up a theory of phonemic duration on the partly shaky partly non-existent basis of half-long duration must necessarily fail. This is the case also with L. Posti's hypothesis that sthe long allochrone occurs only before a half-long vowel of the second syllable ${ }^{1}$." One has only to examine such words as sepik 'whole wheat bread', joodik 'drunkard', vikat 'scythe', kammits 'fetter-lock', vaadet part. sg. 'view, sight', suureks translat. sg. (of nom. suur) 'big, great', hooletu 'careless', oodake imperat. 2nd pl. 'wait', etc., to see the incorrectness of Posti's theory, because in these examples either the vowel of the first syllable or the following consonant is long, and not overlong, but the vowel of the second syllable is not half-long, but is short. In oodake, for example, the average duration of $-a$ - is, according to $\mathrm{my}$ measurements, ca. $0.10 \mathrm{sec}$. (in separately pronounced words), while that of $o 0^{-}$is ca. 0.20 sec. which is equal to the average duration of long vowels; thus the vowel in the 2nd syllable of a word, in which the durations of the other sounds are average, is shorter than the average short vowel of the first syllable. Words such as part. sg. põõsast 'bush, shrub' in contrast with elat. sg. põõsast, part. sg. toorest 'raw' in contrast with elat. sg. toorest, etc., are distinguished not by the duration of the vowel of the 2nd syllable (which is short in both cases) but by the duration of the first syllable, which is long in the partitive and overlong in the elative.

In Finnish the duration of the vowel of an unstressed syllable is indeed distinctive (e.g. nom. sg. kala 'fish' - part. sg. kalaa, gen. sg. kysymyksen 'of the question' - illat. sg. kysymykseen 'into the question', pres. 3rd pl. palavat 'they burn' - palaavat 'they return', etc.). But in Estonian the unstressed (or weakly stressed) long vowels resulting from contraction have been shortened. As result of this their duration has lost its distinctive function, and the pronunciation of Est. part. sg.

1 JSFOu. LIV, 9. 
kala 'fish' (from Proto-Finnic *kalada), for example, is exactly identical with that of nom. sg. kala 'fish' (from PFi. kala). As may be seen from the present investigation, the duration of vowels with primary stress and the consonants following them as well as the duration of consonants following vowels with secondary stress is distinctive in Estonian. There are three different degrees of duration, which may be called chronemes. Because of the loss of distinctive endings (original case terminations, etc.) as a result of phonological developments, different forms of the same paradigm have often become identical and are distinguished solely by quantity, e.g. gen. sg. sepa 'of the smith' coming from Proto-Finnic *sep̌pän and part. sg. seppa from PFi. *seppäßä. The occurrence of duration in distinctive alternation in inflexional paradigms is its most important function in modern Estonian.

Ithaca, N.Y.

U.S.A.

Hildegard Must. 